\title{
Review \\ Mechanisms of High-Grade Serous Carcinogenesis in the Fallopian Tube and Ovary: Current Hypotheses, Etiologic Factors, and Molecular Alterations
}

\author{
Isao Otsuka (D)
}

Citation: Otsuka, I. Mechanisms of High-Grade Serous Carcinogenesis in the Fallopian Tube and Ovary: Current Hypotheses, Etiologic Factors, and Molecular Alterations. Int. J. Mol. Sci. 2021, 22, 4409. https://doi.org/10.3390/ijms 22094409

Academic Editor: Takaaki Masuda

Received: 8 April 2021

Accepted: 20 April 2021

Published: 23 April 2021

Publisher's Note: MDPI stays neutral with regard to jurisdictional claims in published maps and institutional affiliations.

Copyright: (c) 2021 by the author. Licensee MDPI, Basel, Switzerland. This article is an open access article distributed under the terms and conditions of the Creative Commons Attribution (CC BY) license (https:/ / creativecommons.org/licenses/by/ $4.0 /)$.
Kameda Medical Center, Department of Obstetrics and Gynecology, Kamogawa 296-8602, Japan; otsuka.isao@kameda.jp

\begin{abstract}
Ovarian high-grade serous carcinomas (HGSCs) are a heterogeneous group of diseases. They include fallopian-tube-epithelium (FTE)-derived and ovarian-surface-epithelium (OSE)-derived tumors. The risk/protective factors suggest that the etiology of HGSCs is multifactorial. Inflammation caused by ovulation and retrograde bleeding may play a major role. HGSCs are among the most genetically altered cancers, and TP53 mutations are ubiquitous. Key driving events other than TP53 mutations include homologous recombination (HR) deficiency, such as BRCA 1/2 dysfunction, and activation of the CCNE1 pathway. HR deficiency and the CCNE1 amplification appear to be mutually exclusive. Intratumor heterogeneity resulting from genomic instability can be observed at the early stage of tumorigenesis. In this review, I discuss current carcinogenic hypotheses, sites of origin, etiologic factors, and molecular alterations of HGSCs.
\end{abstract}

Keywords: ovarian cancer; high-grade serous carcinoma; carcinogenesis; molecular alterations

\section{Introduction}

Ovarian cancer is the most lethal gynecological malignancy. Epithelial ovarian cancers (EOCs) are a heterogeneous group of diseases and can be divided into five main types, based on histopathology and molecular genetics [1]: high-grade serous, low-grade serous, endometrioid, clear cell, and mucinous tumors. These tumors may be classified into type I and II tumors. Type I tumors include endometriosis-related tumors (endometrioid and clear cell carcinomas), low-grade serous carcinoma, and mucinous carcinoma. Type II tumors are composed of high-grade serous carcinomas, for the most part [2]. Although this classification conflicts with recent molecular insights into the etiology of EOCs [3], type II tumors that also include carcinosarcomas could be classed together.

High-grade serous carcinoma (HGSC) is the most common and lethal subtype of EOC, as most women with HGSC are diagnosed at a late stage, when achieving a cure is rare [4]. The vast majority of serous carcinomas are high-grade tumors [5]. To develop an effective method for prevention and early detection, elucidation of carcinogenesis is essential. Recently, our understanding of the origins and pathogenesis of HGSC has substantially progressed through whole genome and bioinformatic analyses. This review discusses the current carcinogenic hypotheses, sites of origin, etiologic factors, and molecular alterations of HGSCs.

\section{Carcinogenic Hypotheses and Risk/Protective Factors \\ 2.1. Incessant Ovulation}

EOCs were traditionally thought to arise from the ovarian surface epithelium (OSE). The OSE is the pelvic mesothelium that overlies the ovary and lines ovarian epithelial inclusion cysts, and is derived from the coelomic epithelium [6,7]. The risk/protective factors for EOCs include parity, breast-feeding, and oral contraceptive use; all of these factors reduce ovarian cancer risk [8] (Figure 1). These reproductive and hormonal factors 
are associated with ovulation suppression. Thus, the risk of EOC is thought to be associated with the number of ovulatory cycles.

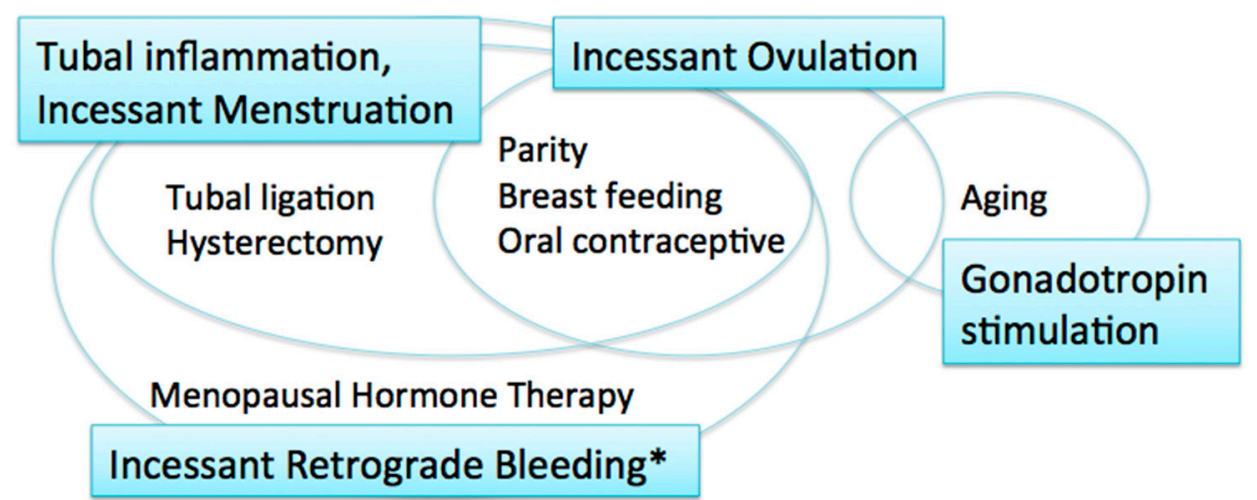

Figure 1. Carcinogenic hypotheses and risk/protective factors. * including menstruation and postmenopausal bleeding.

The incessant ovulation hypothesis was proposed by Fathalla in 1971 based on these observations [9]. This hypothesis proposes that recurrent damage and repair of the OSE from repeated ovulation increase the risk of cell damage and subsequent neoplastic transformation. A study showed that a higher number of ovulatory cycles may be associated with increased amounts of DNA damage [10].

\subsection{Gonadotropin Stimulation}

The majority of women with ovarian cancer present in the postmenopausal period, when pituitary gonadotropin levels are elevated. The gonadotropin stimulation hypothesis proposes that high gonadotropin levels can have an effect on OSE cells and promote carcinogenesis [11,12]. Gonadotropins that persist in high levels for many years after menopause may stimulate the OSE, in which gonadotropin receptors are expressed, and OSE cells may subsequently undergo malignant transformation [12]. Surges of gonadotropins that initiate each ovulation may also play a role in carcinogenesis; thus, the incessant ovulation and gonadotropin hypotheses are interrelated.

\subsection{Tubal Inflammation}

These two hypotheses, however, have limitations. If the number of lifetime ovulatory cycles and exposure to high levels of gonadotropins are associated with EOC development, fertility treatment might increase the risk of EOC via the multiple ovulations stimulated by gonadotropins, specifically luteinizing hormone (LH) and follicle stimulating hormone (FSH). In fact, studies suggest that there is no significant relationship between in vitro fertilization treatment using gonadotropin stimulation and subsequent risk of EOC $[13,14]$. In addition, as the ovulatory rupture sites appear to be random, the repeated rupture and repair that occurs with each ovulation should not affect the same population of surface epithelial cells [15]. Furthermore, neither the incessant ovulation nor gonadotropin stimulation hypotheses explains the protective effect of tubal ligation and hysterectomy on the development of EOC [16].

The fallopian tube, in particular the fimbriae, emerged as another site of origin based on findings related to prophylactic surgery for ovarian cancer risk reduction in women with genetic predisposition to the disease [17]. Based on these observations, the tubal inflammation hypothesis was proposed by Salvador [7]. Chronic inflammation is known to be a risk for cancer. The fallopian tube is regularly exposed to a variety of inflammatory agents, and can show signs of acute and chronic inflammation, through the process of retrograde bleeding from the endometrial cavity during menstruation. Infection also induces inflammation in the fallopian tube [7]. Chlamydia trachomatis infection may be associated with serous carcinogenesis [18]. 


\subsection{Incessant Menstruation}

The incessant menstruation hypothesis, proposed by Vercellini [16], also explains why ovarian cancer risk is decreased by tubal ligation and ovulation suppression. In this theory, pathogenesis of endometriosis-associated carcinomas, specifically endometrioid and clear cell carcinomas, as well as serous carcinomas, can be explained. In serous carcinomas, retrograde menstruation from the endometrial cavity into the Douglas pouch is the causative mechanism that generates fallopian tube inflammation $[7,16]$. The incessant menstruation hypothesis explains ovarian cancer risk well in the premenopausal period. However, in postmenopausal women, another risk factor is related to ovarian carcinogenesis, that is, menopausal hormone therapy (MHT).

\subsection{Incessant Retrograde Bleeding}

Incessant retrograde bleeding is an expansion of the concept of incessant menstruation and may explain more accurately the etiology of HGSCs in both premenopausal and postmenopausal women [19]. Some types of MHT, also called hormone replacement therapy, increase ovarian cancer risk. The risk of serous ovarian cancer differs by regimen of MHT. Its risk in women with intact uteri is increased with the use of estrogen alone, and estrogen with sequentially added progestin [20,21]. Both regimens cause endometrial bleeding. In contrast, serous ovarian cancer risk is not altered by the use of continuous estrogen and progestin, which results in endometrial atrophy with bleeding cessation $[19,21]$. Thus, MHT regimens that cause endometrial bleeding are associated with an increased risk of serous ovarian carcinoma.

\section{Sites of Origin of HGSCs}

Although the dominant site of origin for HGSCs is the distal fallopian tube (fimbriae) [17,22], HGSCs can also arise from the ovary [23-27]. In experimental models, HGSCs developed from both the fallopian tube and ovary with inactivation of a few genes [26,28-30]. Cancer may originate from the transition of stem cells, as the acquisition of multiple mutagenic events can occur in long-lived stem cells that are capable of selfrenewal [31], and stem cells can be found both in the fallopian tube and ovary, in particular in the distal fallopian tube and in the transition area between the OSE, mesothelium, and tubal epithelium $[23,32,33]$.

\subsection{Fallopian Tube Epithelium}

A substantial percentage (60-88\%) of HGSC s originate in the fallopian tube [17,22,25,34,35], both in women with $B R C A$ mutations and in sporadic cases $[2,17,36]$. The molecular profile and immunophenotype of HGSCs are more closely related to the FTE than OSE [22,37,38]. Although fallopian tube epithelial secretory cells are believed to give rise to HGSCs [28], ciliated cells may be another cell-of-origin in the fallopian tube epithelium (FTE) [26].

In the FTE, p53 signatures and serous tubal intraepithelial carcinoma (STIC), both of which are intraepithelial lesions associated with HGSC, can be identified. The p53 signature is a focus of strong p53 immunostaining in benign tubal mucosa [39] and harbors TP53 mutations and evidence of DNA damage [40]. Telomere shortening occurs in p53 signatures, suggesting that the p53 signature is the earliest precancer lesion [41]. However, the p53 signature may not always be a preneoplastic lesion of HGSC, as p53 overexpression has been found to be common both in $B R C A$ carriers and in noncarriers who underwent surgery for benign disease or RRSO [42]. STIC, which is composed of secretory cells showing significant atypia, architectural alterations, a high proliferative index, and strong p53 immunostaining [43], is a putative precursor lesion of HGSC. Identical somatic TP53 mutations have been detected in the majority of pairs of STIC and concurrent HGSCs [44]. However, not all HGSCs may arise from STIC lesions, even in high-risk women [45]. STIC was observed only in 11-61\% (mean 31\%) of HGSCs [46], and some STICs are actually metastases from HGSCs, rather than HGSC precursors [47]. Additionally, a subset of serous tubal intraepithelial neoplasias, including STIC, are an intraepithelial metastasis 
from a contralateral serous tubal intraepithelial neoplasia [48]. STICs and serous tubal intraepithelial lesions (STILs), which are intermediate lesions between the p53 signature and STIC, may not share the protective factors that are associated with HGSC [49]. The development of STICs may be related to random mutations occurring in target cancer drivers, including TP53 [49]. Thus, many potential precursor or premalignant lesions do not advance to malignant tumors or lethal malignancies [45].

\subsection{Ovarian Surface Epithelium}

The OSE is another site of origin for HGSCs. Ovarian carcinoma in situ has been identified in ovaries removed in risk-reducing oophorectomies in women with a germline $B R C A$ mutation [50]. A literature review of microscopic ovarian, fallopian tube, and peritoneal tumors in $B R C A 1 / 2$ mutation carriers showed that $60.5 \%$ were confined to the fallopian tube only, whereas $21.1 \%$ and $2.6 \%$ involved only the ovary and only the peritoneum, respectively [35]. Ovarian epithelial inclusion cysts are considered to be a possible site of origin of HGSCs. HGSCs may frequently arise within epithelial inclusion cysts, but not the surface epithelium itself [51]. A dysplastic precursor lesion within epithelial inclusion cysts, showing accumulation of p53, precedes carcinoma development. Recently, the concept of precursor escape has been postulated. Cells from early precursors, such as early serous proliferations, are shed from the fallopian tube and undergo subsequent malignant transformation on the surface of the ovary and peritoneum [52]. There are two known types of ovarian inclusion cysts; one is positive for PAX8 (mullerian marker), and the other is positive for calretinin (mesothelial marker) [53]. However, they may not represent FTE-derived and OSE-derived cysts, as many PAX8-positive cells arise from metaplasia of OSE-derived inclusion cysts [54]. In a mouse model, ectopic tubal-type epithelium (endosalpingiosis) in the ovary did not likely arise as a consequence of detachment and implantation of the tubal epithelium [55].

FTE-derived and OSE-derived HGSCs are different in their pattern of metastasis, transcriptome, and response to chemotherapy [26]. FTE-derived tumors have a greater propensity to disseminate, whereas OSE-derived tumors form large, solitary lesions, with less frequent metastasis [26]. OSE-derived HGSC may have a long latent period and a poor prognosis compared to FTE-derived HGSC [24,25]. The poorer prognosis associated with OSE-derived HGSC may partly be explained by its mesenchymal characteristics. OSE cells have a dual epithelia-mesenchymal phenotype [56], and in the mouse ovaries leiomyosarcoma developed with inactivation of Brca1 and Trp53 [57]. A histological subtype showing mesenchymal characteristics had the lowest overall survival among four histological subtypes of HGSC [58].

\section{Etiologic Factors}

The etiology of HGSCs appears to be multifactorial (Figure 2). Inflammation, which is induced by follicular fluid released at ovulation and by blood from the endometrial cavity, may play a major role in high-grade serous carcinogenesis [7,16,59-63]. At sites of inflammation, epithelial cells are exposed to high levels of inflammatory mediators such as reactive oxygen species (ROS), cytokines, and growth factors, which contribute to cell proliferation, genetic and epigenetic changes, and cancer development [64]. 


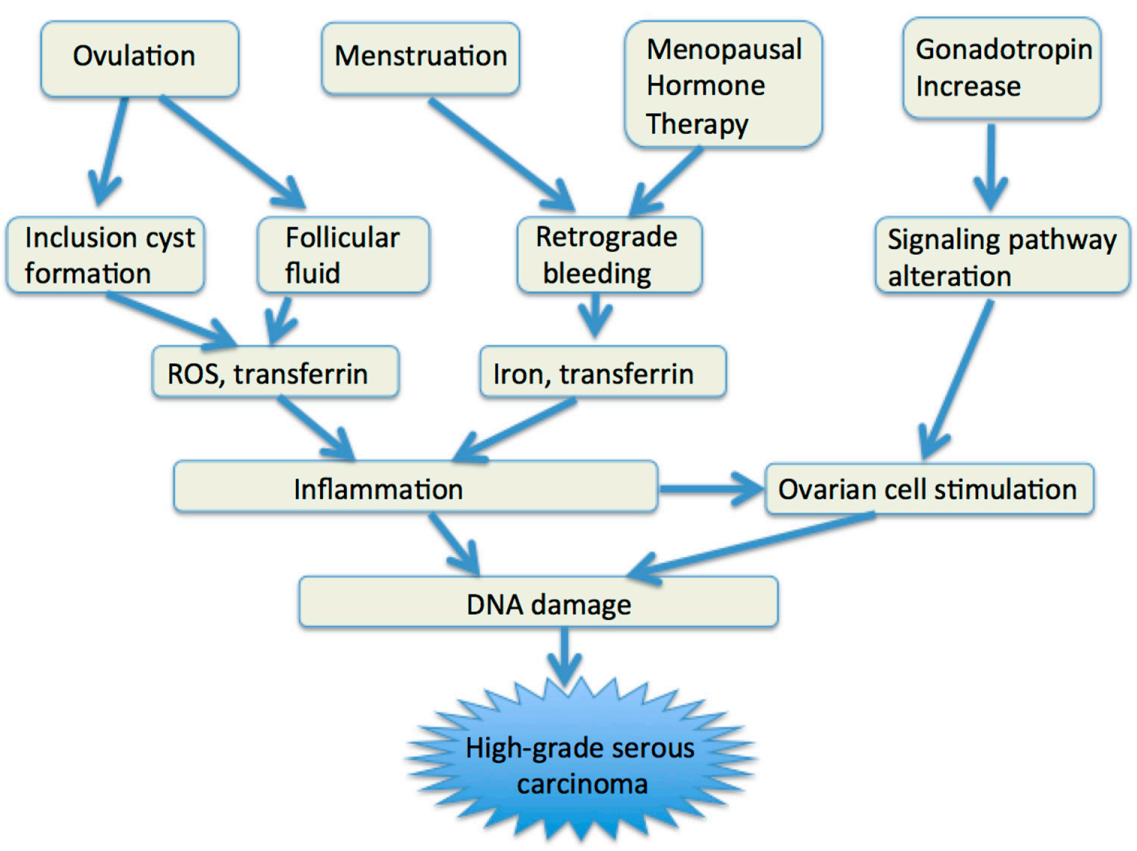

Figure 2. Etiologic factors of HGSCs. ROS, reactive oxygen species.

\subsection{Ovulation}

Ovulation may be associated with high-grade serous carcinogenesis via two aspects: follicular fluid release and inclusion cyst formation. Ovulation is an acute inflammatory process [59], and follicular fluid released from ovulation bathes the fimbrial epithelium and OSE [60]. ROS contained in follicular fluid induce inflammation and DNA double-strand breaks, leading to apoptosis, but if apoptotic failure occurs, neoplastic transformation in fimbrial and ovarian epithelial cells may occur [60-62,65]. Exposure of the FTE to follicular fluid can lead to activation of the NF-kB-miR-155 axis, which may represent a possible link between inflammation and DNA damage [62]. Insulin growth factor axis proteins in the follicular fluid confer stemness activation and clonal expansion [63]. Progesterone may prevent ovarian cancer by eliminating p53-deficient epithelial cells [65].

Incessant ovulation may increase the risk of EOC by increasing the risk of inclusion cyst formation. After ovulation, the OSE may invaginate to form clefts and inclusion cysts. Entrapment of exfoliated FTE cells or OSE cells may be an initial event in ovarian carcinogenesis. The estrogen-rich ovarian stromal microenvironment constantly stimulates these cells to proliferate and may cause malignant proliferation. The use of oral contraceptive pills prevents the development of cortical inclusion cysts lined by tubal type epithelium [66].

\subsection{Retrograde Bleeding}

Retrograde bleeding from the endometrial cavity into the Douglas pouch, a normal phenomenon during menstrual periods, and subsequent iron-induced oxidative stress, is a causative mechanism of HGSC. The FTE and OSE are bathed in the blood from the endometrial cavity and exposed to the action of catalytic iron and the genotoxic effect of ROS [16]. Iron is an essential nutrient that facilitates cell proliferation and growth, but it also can contribute to tumor initiation and growth. In concert with ROS, transferrin and ferryl hemoglobin, both of which are contained in blood and follicular fluid, may contribute to high-grade serous carcinogenesis $[67,68]$. Transferrin induces DNA double-strand breaks in murine FTE that may lead to genome instability [67]. Ferryl hemoglobin could rescue p53-deficient fimbrial epithelial cells from lethal ROS stress by consuming extracellular ROS and reducing NADPH oxidase-mediated cell death [68]. Oxidative stress caused by ROS can activate a variety of transcription factors, such as NF- $\mathrm{B}, \mathrm{p} 53$, and $\mathrm{Wnt} / \beta$-catenin, 
and lead to chronic inflammation [69,70]. Menstrual cytokines, such as tumor necrosis factor (TNF) $\alpha$ and interleukin 8 , also cause inflammation [7].

\subsection{Gonadotropin}

Gonadotropins-in particular, FSH—-may be involved in high-grade serous carcinogenesis. FSH receptor is present in the majority of ovarian epithelial inclusion cysts and ovarian epithelial tumors, suggesting that FSH is an important ovarian epithelial cell growth-promoting factor [71]. FSH promotes proliferation and prevents apoptosis of ovarian cancer cells by activating survivin [72] and supports tumor growth by inducing increased expression of vascular endothelial growth factor (VEGF) [73]. In postmenopausal women, increased FSH levels may foster an inflammatory environment that cannot cause ovulation but may increase ovarian cancer risk through remodeling or morphological changes in the surface epithelium [74]. FSH may alter certain signaling pathways and gene expressions, and result in enhanced proliferation and invasion [12,75].

\section{Molecular Alterations}

HGSCs are among the most genetically altered cancers and are characterized by a few driver mutations and a large number of somatic copy number alterations [76,77]. Driver gene mutations result in inactivation of tumor suppressors and copy number amplifications, leading to an increase in oncogene activity. TP53 mutations are ubiquitous in HGSCs [78-80]. Additional genetic alterations in HGSCs include alterations in the homologous recombination (HR) pathway and alterations in the $\mathrm{Rb}$ pathway, or alterations in genes involved in Rb-mediated DNA repair and cell cycle control (Figure 3). HR pathway defects, including BRCA1/2 dysfunction, appear to be present in at least $50 \%$ of these cancers, and alterations in the Rb cell cycle regulation pathway, including CCNE1 and $R B 1$ dysfunction, are observed in about $30 \%$ [79,81]. Notably, inactivation of $B R C A 1$ and $B R C A 2$ is mutually exclusive of amplification of CCNE1 and inactivation of RB1 [81,82]. HGSCs can acquire genomic instability via alterations to either pathway [82]. Nearly half of HGSCs have no oncogenic mutations other than TP53 [83].

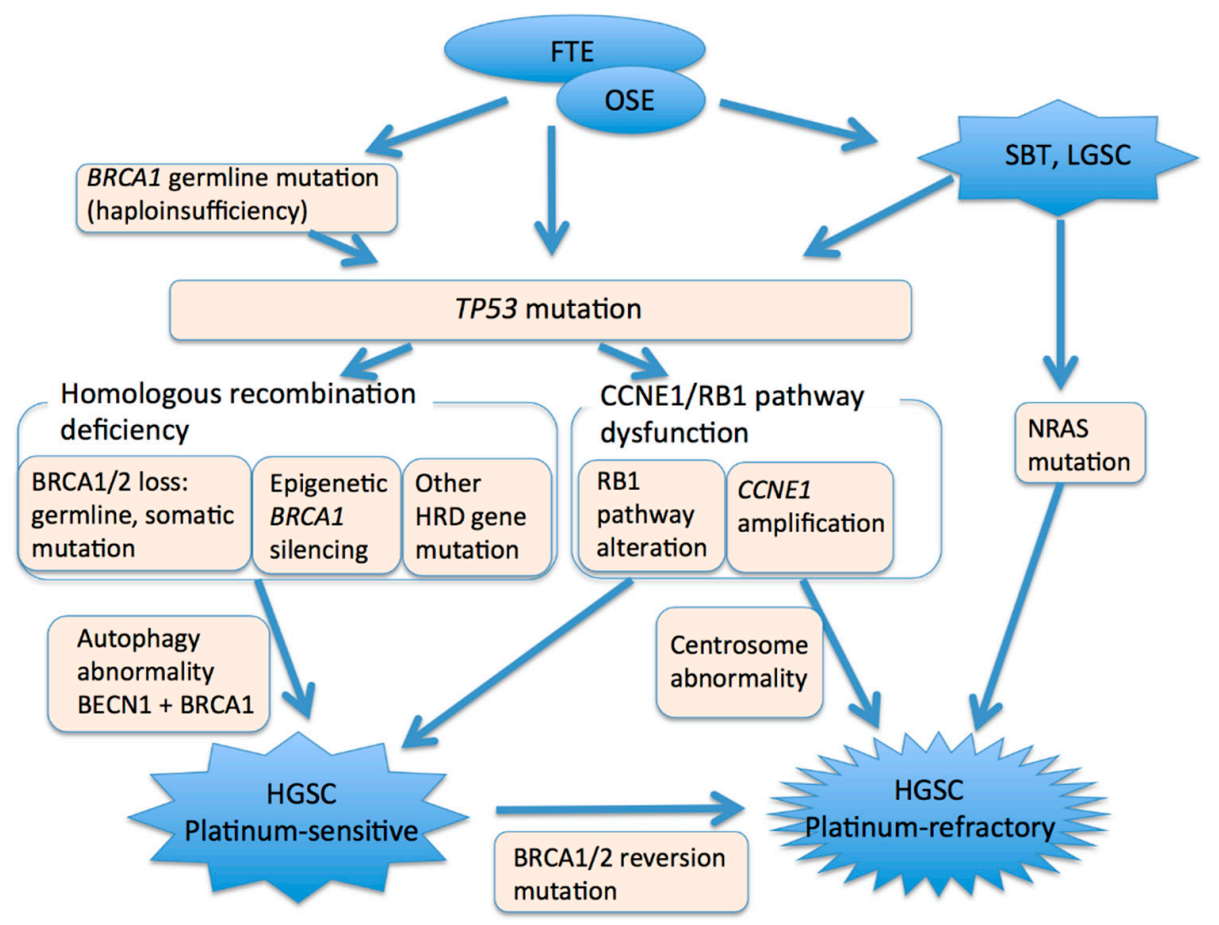

Figure 3. A model of high-grade serous carcinogenesis. FTE, fallopian tube epithelium. OSE, ovarian surface epithelium. SBT, serous borderline tumor. LGSC, low-grade serous carcinoma. HGSC, high-grade serous carcinoma. 


\subsection{TP53}

Somatic mutation of TP53, which encodes the tumor suppressor p53, is a driver mutation in high-grade serous carcinogenesis. In studies, TP53 mutations have been identified in $96 \%$ of HGSCs [78,79], and are the earliest events in high-grade serous carcinogenesis $[84,85]$. p53 is responsive to many stress signals and orchestrates diverse cell responses to maintain and restore cell/tissue functions [86]. In response to cellular stresses, such as DNA damage, p53 restrains inappropriate cellular proliferation by triggering transient cell cycle arrest, permanent cell cycle arrest (cellular senescence), and apoptosis; all of these are processes associated with tumor suppression. p53 stimulates various DNA repair mechanisms [87], and its deficiency may permit multiple mutational processes to evolve simultaneously and can enhance cancer initiation [88]. Tumors that lack p53 are commonly characterized by more malignant characteristics, such as poor differentiation and genetic instability [87].

TP53 mutations in ovarian cancer arise due to spontaneous errors in DNA synthesis and repair, rather than the direct effect of carcinogens [89,90]. During tumor development, a TP53 mutation is typically followed by loss of heterozygosity, which results in complete p53 deficiency [87]. However, loss of p53 function alone does not produce the malignant phenotype, and at least one more genotoxic event, such as BRCA1/2 inactivation, is necessary [40].

TP53 mutations are heterogeneous and occur at almost every codon in the DNAbinding domain of the gene [91]. While loss of function of p53 promotes tumorigenesis, TP53 mutations may also lead to the development of gain of function (oncomorphic) p53 proteins, which also promote tumorigenesis [91,92]. Oncomorphic TP53 mutations have been found to be present in $21.3 \%$ of ovarian cancers [91].

\section{2. $B R C A 1 / 2$}

BRCA1/2 dysfunction through germline or somatic mutations of $B R C A 1 / 2$, or epigenetic silencing of $B R C A 1$ by promoter hypermethylation, is involved in the development of HGSCs [79]. Germline or somatic mutations in BRCA1/2 have been observed in $20 \%$ of cases, and $11 \%$ lost $B R C A 1$ expression through epigenetic silencing. Germline or somatic $B R C A 1 / 2$ mutations are mutually exclusive of epigenetic silencing of $B R C A 1$ [79]. $B R C A 1$ mutation is distinct from $B R C A 2$ mutation in several aspects. $B R C A 1$ mutations are more common than BRCA2 mutations in HGSCs. Pathogenic germline BRCA1 mutations, but not $B R C A 2$ mutations, are more common in younger patients [93]. The cumulative risk of developing ovarian cancer by age 80 years is $44 \%$ for $B R C A 1$ and $17 \%$ for $B R C A 2$ carriers [94]. BRCA1 mutations are almost exclusively associated with female breast and ovarian cancer, whereas $B R C A 2$ families are also at risk for male breast cancer, pancreatic cancer in both males and females, and prostate cancers [95]. In EOCs, germline BRCA1 and $B R C A 2$ mutations are exclusively associated with high-grade serous histology, and $25 \%$ of ovarian HGSCs develop in women with these mutations [96].

$B R C A 1$ plays a key role in the maintenance of genomic integrity, which is an essential component of its tumor-suppressing function [97]. BRCA1 is critical in double-strand break repair, utilizing HR. Biallelic inactivation of $B R C A 1$ is embryonic lethal in mice and, similarly, it is thought to result in cellular lethality in human cells [98]. Tumors with loss of $B R C A 1$ function require additional somatic mutations, such as in TP53, to suppress induction of DNA damage cell cycle checkpoints and escape cell cycle arrest or apoptosis caused by genomic instability [99]. Of note, heterozygous BRCA1 inactivation results in genomic instability in nontumorigenic breast epithelial cells [98], and heterozygous mutations in BRCA1 and BRCA2 have been shown to contribute to development of HGSC in an ovarian cancer mouse model [100]. Downregulation of BRCA1 to levels similar to those present in women with $B R C A 1$ mutation results in overcoming of the spindle assembly checkpoint [101]. These observations suggest that haploinsufficiency (loss of only one allele) of $B R C A 1$ may accelerate cancer initiation in women with germline $B R C A 1$ mutations by facilitating additional genetic alterations [98]. TP53 mutation, which is caused 
by BRCA1 haploinsufficiency, may be associated with the early occurrence of HGSCs in women with germline $B R C A 1$ mutations.

Not all tumors associated with germline $B R C A 1$ and $B R C A 2$ mutations show a loss of BRCA1 or BRCA2 function. Retention of the normal $B R C A 1$ or $B R C A 2$ allele is observed in $7 \%$ and $16 \%$ of $B R C A 1$ and BRCA2 germline mutation-associated ovarian cancers, and it is associated with decreased overall survival in patients treated with platinum chemotherapy [99].

$B R C A 2$-mutated cases, but not $B R C A 1$-mutated cases, indicate a mutator phenotype that contains significantly more mutations [95]. The proteins encoded by BRCA1 and $B R C A 2$ work in a common pathway of genomic protection. However, the two proteins work at different stages in the DNA damage response and in DNA repair, and their specific roles are different [102]. As BRCA1 is a pleiotropic DNA damage response protein, its role in DNA repair is broader than that of BRCA2. BRCA1 functions in both checkpoint activation and DNA repair, whereas BRCA2 is a mediator of the core mechanism of HR [102]. BRCA2-mutated HGSCs are clinically distinct from BRCA1-mutated HGSCs [103]. $B R C A 2$ mutations may be associated with improved survival compared with either $B R C A$ wild-type or a BRCA1 mutations in ovarian HGSCs [95,103].

HR DNA repair defects may be present in approximately half of all ovarian HGSC cases $[79,104]$. Biallelic alterations of HR genes such as BRCA1, BRCA2, ATM, BRIP1, and $R A D 51 D$ are mutually exclusive of each other in ovarian HGSCs [105].

\subsection{CCNE1 and $R b 1$}

Amplification of CCNE1, which encodes cyclin E1, is a primary oncogenic driver in a subset of HGSCs. CCNE1 and RB1 are components of the Rb cell cycle regulation pathway. Cyclin E1 binds to cyclin-dependent kinase 2 (CDK2) and plays an important role in cell cycle progression and in centrosome duplication, which is a strictly regulated process that maintains genetic stability [106]. Amplification of the CCNE1 copy number occurs early in tumor progression and precedes centrosome amplification [106]. CCNE1 amplification and RB1 deletion accelerate the cell cycle, resulting in defective $S$ phase progression and increased chromosome breakage [107]. More than two centrosomes in a cell promote aberrant centrosome duplication and result in chromosomal instability after cytokinesis [106]. CCNE1 amplification and RB1 dysfunction are observed in $20 \%$ and $10 \%$ of HGSCs, respectively [79]. CCNE1 amplification is more frequent in older women [93] and is associated with a poor prognosis [108].

\subsection{Autophagy Gene}

HGSC is the most severely disrupted in terms of autophagy and in compensatory proteostasis pathways among 21 cancer types [83]. Autophagy is an intracellular catabolic degradative process targeting damaged and superfluous cellular proteins, organelles, and other cytoplasmic components [109], and contributes to cell homeostasis and survival [110]. Autophagy is involved in cancer initiation and cancer (stem) cell maintenance [111,112]. In the cancer microenvironment, autophagy can have two functions. In stromal cells, it contributes to tumorigenesis by generating and supplying nutrients to cancerous cells, whereas in immune cells, it may help to support anticancer immune responses [112]. Haploinsufficiency of an autophagy gene, BECN1, which is almost always codeleted with $B R C A 1$, may permit tumor initiation and potentiate genomic instability in ovarian cancer [76].

\subsection{Stem Cell Markers}

Stem cell markers may be linked to high-grade serous carcinogenesis. Stem cells at the ovarian hilum in mice express a stem cell marker, aldehyde dehydrogenase isoform 1A1 (ALDH1A1), and its loss of expression is an early event in HGSC development [113]. SOX2 (sex-determining region Y-box2), which is a key stem cell differentiation gene and is 
required to maintain cancer stem cells [114], is involved in regulation of cancer stem cells, and SOX2 overexpression may occur earlier than TP53 mutation [115].

\subsection{Transition from Low-Grade Serous Carcinoma}

HGSCs may arise from serous borderline tumors and low-grade serous carcinoma. NRAS mutation and secondary TP53 mutation are oncogenic drivers associated with progression from low-grade tumors to high-grade tumors [116,117]. In addition, HGSCs closely associated with serous borderline tumors and low-grade serous carcinoma that lack a TP53 mutation have been reported [118].

\section{Clinical Relevance}

To prevent HGSC development, suppression of the inflammation caused by ovulation and retrograde bleeding may be effective, as well as surgical risk reduction, such as RRSO. Combined OC (estrogen plus progestin) use reduces ovarian cancer risk in women with a BRCA mutation [119]. Extended and continuous regimens of combined OC use may be more effective than monthly OCs, which are associated with monthly bleeding. Antiinflammatory drug use during a bleeding period may reduce ovarian cancer risk [120].

Screening for ovarian HGSC needs to detect precursors of FTE-derived and OSEderived HGSCs. The p53 signature may take a long time (20 years or more) to develop into STIC, whereas STIC may progress to invasive carcinoma in 6-7 years [121-123]. For FTEderived HGSCs, the detection of exfoliated cells and tumor DNA from samples obtained from the endometrial cavity or the cervix may be useful, as precancer or cancer cells in the fallopian tube flow into the endometrial cavity $[19,124]$. OSE-derived HGSC can be detected early using transvaginal ultrasonography in asymptomatic women aged $\geq 50$ years, or in women aged $\geq 25$ years with a family history of ovarian cancer [125]. SOX2 overexpression, not p53 overexpression, may be used as a molecular precursor for early detection of HGSCs in the fallopian tube [115]. Whereas p53 overexpression (p53 signature) only involves a limited number of cells, SOX2 overexpression is broadly expressed in the non-neoplastic FTE of patients with HGSCs, and also in the normal FTE of BRCA1 or BRCA2 mutation carriers who are at high risk for HGSCs.

The mechanisms underlying carcinogenesis are highly associated with treatment response. HR deficient tumors-in particular, $B R C A$ dysfunction-are sensitive to platinumbased chemotherapy and PARP inhibitors [104,126,127]. In contrast, HR proficient tumors, such as tumors with $C C N E 1$ amplification, exhibit primary resistance to these therapies $[128,129]$ and have a poor prognosis [108]. Tumors with BRCA1/2 dysfunction also respond to immune checkpoint inhibitors [130,131]. In advanced tumors, pretreatment tumor biopsy can be used to predict whether primary complete cytoreductive surgery can be performed [132].

\section{Concluding Remarks}

HGSCs are a heterogeneous group of diseases, and distinct in their site of origin and oncogenic mechanisms $[79,133]$. Inflammation in the FTE and OSE, caused by ovulation and retrograde bleeding, appears to be associated with their carcinogenesis. Extensive genomic instability, a characteristic of HGSCs, is caused by TP53 mutation, HR deficiency, and chromosomal instability. Intratumor heterogeneity resulting from genomic instability can be observed at the early stage of tumorigenesis [84,122]. Subclonal tumor populations are present in pretreatment biopsies [134], and recurrent and platinum-resistant tumors develop from pre-existing minor clones [135]. Extensive intratumor heterogeneity limits the effectiveness of targeted therapy, as well as that of chemotherapy, since the targeting of somatic events in all cancer cells is necessary for targeted therapies to be effective [136]. Combinations of targeted therapeutic strategies for multiple clonal or subclonal events may be effective, but their economic and toxicity costs may limit the use of these approaches [136]. 
The existence of extensive intratumor heterogeneity in HGSCs supports the progression and ultimate lethality of the disease [137]. Therefore, the disease needs to be detected at an early stage, when complete resection of the tumor, which is most associated with long-term survival [138], can be performed. To develop effective methods for prevention and early detection of HGSCs, further studies are needed to identify risk factors separately by site of origin and carcinogenic pathway.

Funding: This research received no external funding.

Institutional Review Board Statement: Not applicable.

Informed Consent Statement: Not applicable.

Conflicts of Interest: The author declares no conflict of interest.

\section{References}

1. Prat, J.; D'Angelo, E.; Espinosa, I. Ovarian carcinomas: At least five different diseases with distinct histological features and molecular genetics. Hum. Pathol. 2018, 80, 11-27. [CrossRef]

2. Kurman, R.J.; Shih, I.M. The dualistic model of ovarian carcinogenesis: Revisited, revised, and expanded. Am. J. Pathol. 2016, 186, 733-747. [CrossRef]

3. Salazar, C.; Campbell, I.G.; Gorringe, K.L. When Is “Type I" Ovarian Cancer Not "Type I"? Indications of an Out-Dated Dichotomy. Front. Oncol. 2018, 8, 654. [CrossRef]

4. Bowtell, D.D. The genesis and evolution of high-grade serous ovarian cancer. Nat. Rev. Cancer 2010, 10, 803-808. [CrossRef]

5. Bodurka, D.C.; Deavers, M.T.; Tian, C.; Sun, C.C.; Malpica, A.; Coleman, R.L.; Lu, K.H.; Sood, A.K.; Birrel, M.J.; Ozols, R.; et al. Reclassification of serous ovarian carcinoma by a 2-tier system. A Gynecologic Oncology Group study. Cancer 2012, 119, 3087-3094. [CrossRef] [PubMed]

6. Auersperg, N.; Woo, M.M.; Gilks, C.B. The origin of ovarian carcinomas: A developmental view. Gynecol. Oncol. 2008, 110, 452-454. [CrossRef] [PubMed]

7. Salvador, S.; Gilks, B.; Köbel, M.; Huntsman, D.; Rosen, B.; Miller, D. The fallopian tube: Primary site of most pelvic high-grade serous carcinomas. Int. J. Gynecol. Cancer 2009, 19, 58-64. [CrossRef] [PubMed]

8. Menon, U.; Karpinskyj, C.; Gentry-Maharaj, A. Ovarian Cancer Prevention and Screening. Obstet Gynecol. 2018, $131,909-927$. [CrossRef] [PubMed]

9. Fathalla, M.F. Incessant ovulation-A factor in ovarian neoplasia? Lancet 1971, 2, 163. [CrossRef]

10. Schildkraut, J.M.; Bastos, E.; Berchuck, A. Relationship between lifetime ovulatory cycles and overexpression of mutant p53 in epithelial ovarian cancer. J. Natl. Cancer Inst. 1997, 89, 932-938. [CrossRef]

11. Stadel, B.V. The etiology and prevention of ovarian cancer. Am. J. Obstet Gynecol. 1975, 123, 772-774. [CrossRef]

12. Mertens-Walker, I.; Baxter, R.C.; Marsh, D.J. Gonadotropin signalling in epithelial ovarian cancer. Cancer Lett. 2012, 324, 152-159. [CrossRef] [PubMed]

13. Siristatidis, C.T.N.; Sergentanis, P.; Kanavidis, P.; Trivella, M.; Sotiraki, M.; Marvromatis, I.; Psaltopoulou, T.; Skalkidou, A.; Petridou, E.T. Controlled ovarian hyperstimulation for IVF: Impact on ovarian, endometrial and cervical cancer-A systematic review and meta-analysis. Hum. Reprod Update 2013, 19, 105-123. [CrossRef] [PubMed]

14. Gronwald, J.; Glass, K.; Rosen, B.; Karlan, B.; Tung, N.; Neuhausen, S.L.; Moller, P.; Ainsworth, P.; Sun, P.; Narod, S.A.; et al. Treatment of infertility does not increase the risk of ovarian cancer among women with a BRCA1 or BRCA2 mutation. Fertil Steril 2016, 105, 781-785. [CrossRef] [PubMed]

15. Smith, E.R.; Xu, X.X. Etiology of epithelial ovarian cancer: A cellular mechanism for the role of gonadotropins. Gynecol. Oncol. 2003, 91, 1-2. [CrossRef]

16. Vercellini, P.; Crosignani, P.; Somigliana, E.; Vigano, P.; Buggio, L.; Bolis, G.; Fedele, L. The incessant menstruation' hypothesis: A mechanistic ovarian cancer model with implications for prevention. Hum. Reprod 2011, 26, 2262-2273. [CrossRef]

17. Crum, C.P.; Drapkin, R.; Kindelberger, D.; Medeiros, F.; Miran, A.; Lee, Y. Lessons from BRCA: The tubal fimbria emerges as an origin for pelvic serous cancer. Clin. Med. Res. 2007, 5, 35-44. [CrossRef]

18. Idahl, A.; Le Cornet, C.; Maldonado, S.G.; Waterboer, T.; Bender, N.; Tjønneland, A.; Hansen, L.; Boutron-Ruault, M.-C.; Fournier, A.; Kvaskoff, M.; et al. Serologic markers of Chlamydia trachomatis and other sexually transmitted infections and subsequent ovarian cancer risk: Results from the EPIC cohort. Int. J. Cancer 2020, 147, 2042-2052. [CrossRef]

19. Otsuka, I.; Matsuura, T. Screening and prevention for high-grade serous carcinoma of the ovary based on carcinogenesisFallopian tube- and ovarian-derived tumors and incessant retrograde bleeding. Diagnostics 2020, 10, 120. [CrossRef]

20. Riman, T.; Dickman, P.W.; Nilsson, S.; Correia, N.; Nordlinder, H.; Magnusson, C.M.; Weiderpass, E.; Persson, I.R. Hormone replacement therapy and the risk of invasive epithelial ovarian cancer in Swedish women. J. Natl Cancer Inst. 2002, 94, 497-504. [CrossRef]

21. Koskela-Niska, V.; Riska, A.; Lyytinen, H.; Pukkala, E.; Ylikorkala, O. Primary fallopian tube carcinoma risk in users of postmenopausal hormone therapy in Finland. Gynecol. Oncol. 2012, 126, 241-244. [CrossRef] 
22. Ducie, J.; Dao, F.; Considine, M.; Olvera, N.; Shaw, P.A.; Kurman, R.J.; Shih, I.M.; Soslow, R.A.; Cope, L.; Levine, D.A. Molecular analysis of high-grade serous ovarian carcinoma with and without associated serous tubal intra-epithelial carcinoma. Nat. Commun. 2017, 8, 990. [CrossRef] [PubMed]

23. Ng, A.; Tan, S.; Singh, G.; Rizk, P.; Swathi, Y.; Tan, T.Z.; Huang, R.Y.; Leushacke, M.; Barker, N. Lgr5 marks stem/progenitor cells in ovary and tubal epithelia. Nat. Cell. Biol. 2014, 16, 745-757. [CrossRef] [PubMed]

24. Coscia, F.; Watters, K.M.; Curtis, M.; Eckert, M.A.; Chiang, C.Y.; Tyanova, S.; Montag, A.; Lastra, R.R.; Lengyel, E.; Mann, M. Integrative proteomic profiling of ovarian cancer cell lines reveals precursor cell associated proteins and functional status. Nat. Commun. 2016, 7, 12645. [CrossRef]

25. Hao, D.; Li, J.; Jia, S.; Meng, Y.; Zhang, C.; Di, L.-J. Integrated analysis reveals tubal- and ovarian-originated serous ovarian cancer and predicts differential therapeutic responses. Clin. Cancer Res. 2017, 23, 7400-7411. [CrossRef] [PubMed]

26. Zhang, S.; Dolgalev, I.; Zhang, T.; Ran, H.; Levine, D.A.; Neel, B.G. Both fallopian tube and ovarian surface epithelium are cells-of-origin for high-grade serous ovarian carcinoma. Nat. Commun. 2019, 10, 5367. [CrossRef] [PubMed]

27. Geistlinger, L.; Oh, S.; Ramos, M.; Schiffer, L.; Larue, R.S.; Henzler, C.M.; Munro, S.A.; Daughters, C.; Nelson, A.C.; Winterhoff, B.J.; et al. Multiomic Analysis of Subtype Evolution and Heterogeneity in High-Grade Serous Ovarian Carcinoma. Cancer Res. 2020, 80, 4335-4345. [CrossRef]

28. Karst, A.M.; Levanon, K.; Drapkin, R. Modeling high-grade serous ovarian carcinogenesis from the fallopian tube. Proc. Natl. Acad. Sci. USA 2011, 108, 7547-7552. [CrossRef]

29. Szabova, L.; Yin, C.; Bupp, S.; Guerin, T.M.; Schlomer, J.L.; Householder, D.B.; Baran, M.L.; Yi, M.; Song, Y.; Sun, W.; et al. Perturbation of Rb, p53, and Brca1 or Brca2 cooperate in inducing metastatic serous epithelial ovarian cancer. Cancer Res. 2012, 72, 4141-4153. [CrossRef]

30. Zhai, Y.; Wu, R.; Kuick, R.; Sessine, M.S.; Schulman, S.; Green, M.; Fearon, E.R.; Cho, K.R. High-grade serous carcinomas arise in the mouse oviduct via defects linked to the human disease. J. Pathol. 2017, 243, 16-25. [CrossRef]

31. Reya, T.; Morrison, S.J.; Clarke, M.F.; Weissman, I.L. Stem cells, cancer, and cancer stem cells. Nature 2001, 414, 105-111. [CrossRef] [PubMed]

32. Paik, D.Y.; Janzen, D.M.; Schafenacker, A.M.; Velasco, V.S.; Shung, M.S.; Chieng, D.; Huang, J.; Witte, O.N.; Memarzadeh, S. Stem-like epithelial cells are concentrated in the distal end of the fallopian tube: A site for injury and serous cancer initiation. Stem Cells 2012, 30, 2487. [CrossRef] [PubMed]

33. Flesken-Nikitin, A.; Hwang, C.I.; Cheng, C.Y.; Michurina, T.V.; Enikolopov, G.; Nikitin, A.Y. Ovarian surface epithelium at the junction area contains a cancer-prone stem cell niche. Nature 2013, 495, 241-245. [CrossRef] [PubMed]

34. Crum, C.P. Intercepting pelvic cancer in the distal fallopian tube: Theories and realities. Mol. Oncol. 2009, 3, 165-170. [CrossRef] [PubMed]

35. Yates, M.S.; Meyer, L.A.; Deavers, M.T.; Daniels, M.S.; Keeler, E.R.; Mok, S.C.; Gershenson, D.M.; Lu, K.H. Microscopic and early-stage ovarian cancers in BRCA1/2 mutation carriers: Building a model for early BRCA-associated tumorigenesis. Cancer Prev. Res. 2011, 4, 463-470. [CrossRef] [PubMed]

36. Gilks, C.B.; Irving, J.; Köbel, M.; Lee, C.; Singh, N.; Wilkinson, N.; McCluggage, W.G. Incidental Nonuterine High-grade Serous Carcinomas Arise in the Fallopian Tube in Most Cases Further Evidence for the Tubal Origin of High-grade Serous Carcinomas. Am. J. Surg Pathol. 2015, 39, 357-364. [CrossRef]

37. Xiang, L.; Rong, G.; Zhao, J.; Wang, Z.; Shi, F. Identification of candidate genes associated with tubal origin of high-grade serous ovarian cancer. Oncol. Lett. 2018, 15, 7769-7775. [CrossRef]

38. Beirne, J.P.; McArt, D.G.; Roddy, A.; McDermott, C.; Ferris, J.; Buckley, N.E.; Coulter, P.; McCabe, N.; Eddie, S.I.; McCluggage, W.G.; et al. Defining the molecular evolution of extrauterine high grade serous carcinoma. Gynecol. Oncol. 2019, 155, 305-317. [CrossRef]

39. Lee, Y.; Miron, A.; Drapkin, R.; Nucci, M.R.; Medeiros, F.; Saleemuddin, A.; Garber, J.; Birch, C.; Mou, H.; Gordon, R.W.; et al. A candidate precursor to serous carcinoma that originates in the distal fallopian tube. J. Pathol. 2007, 211, 26-35. [CrossRef]

40. Xian, W.; Miron, A.; Roh, M.; Semmel, D.R.; Yassin, Y.; Garber, J.; Oliva, E.; Goodman, A.; Mehra, K.; Berkowitz, R.S.; et al. The Li-Fraumeni syndrome (LFS): A model for the initiation of p53 signatures in the distal Fallopian tube. J. Pathol. 2010, 220, 17-23. [CrossRef]

41. Asaka, S.; Davis, C.; Lin, S.-F.; Wang, T.-L.; Heaphy, C.M.; Shih, I.-M. Analysis of Telomere Lengths in p53 Signatures and Incidental Serous Tubal Intraepithelial Carcinomas without Concurrent Ovarian Cancer. Am. J. Surg. Pathol. 2019, 43, $1083-1091$. [CrossRef]

42. Mehra, K.K.; Chang, M.C.; Folkins, A.K.; Raho, C.J.; Lima, J.F.; Yuan, L.; Mehrad, M.; Tworoger, S.S.; Crum, C.P.; Saleemuddin, A. The impact of tissue block sampling on the detection of p53 signatures in fallopian tubes from women with BRCA 1 or 2 mutations (BRCA+) and controls. Mod. Pathol. 2011, 24, 152-156. [CrossRef] [PubMed]

43. Horn, L.C.; Kafkova, S.; Leonhardt, K.; Kellner, C.; Einenkel, J. Serous tubal in situ carcinoma (STIC) in primary peritoneal serous carcinomas. Int. J. Gynecol. Pathol. 2013, 32, 339-344. [CrossRef] [PubMed]

44. Kuhn, E.; Kurman, R.J.; Vang, R.; Sehdev, A.S.; Han, G.; Soslow, R.; Wang, T.L.; Shih, I.M. TP53 mutations in serous tubal intraepithelial carcinoma and concurrent pelvic high-grade serous carcinoma-Evidence supporting the clonal relationship of the two lesions. J. Pathol. 2012, 226, 421-426. [CrossRef] 
45. Kim, J.; Park, E.Y.; Kim, O.; Schilder, J.M.; Coffey, D.M.; Cho, C.H.; Bast, R.C., Jr. Cell Origins of High-Grade Serous Ovarian Cancer. Cancers 2018, 10, 433. [CrossRef] [PubMed]

46. Chen, F.; Gaitskell, K.; Garcia, M.J.; Albukhari, A.; Tsaltas, J.; Ahmed, A.A. Serous tubal intraepithelial carcinomas associated with high-grade serous ovarian carcinomas: A systematic review. BJOG 2017, 124, 872-878. [CrossRef] [PubMed]

47. Eckert, M.A.; Pan, S.; Hernandez, K.M.; Loth, R.M.; Andrade, J.; Volchenboum, S.L.; Faber, P.; Montag, A.; Lastra, R.; Peter, M.E.; et al. Genomics of ovarian cancer progression reveals diverse metastatic trajectories including intraepithelial metastasis to the fallopian tube. Cancer Discov. 2016, 6, 1342-1351. [CrossRef]

48. Meserve, E.E.; Strickland, K.C.; Miron, A.; Soong, T.R.; Campbell, F.; Howitt, B.E.; Crum, C.P. Evidence of a Monoclonal Origin for Bilateral Serous Tubal Intraepithelial Neoplasia. Int. J. Gynecol. Pathol. 2019, 38, 443-448. [CrossRef]

49. Visvanathan, K.; Shaw, P.; May, B.J.; Bahadirli-Talbott, A.; Kaushiva, A.; Risch, H.; Narod, S.; Wang, T.L.; Parkash, V.; Vang, R.; et al. Fallopian Tube Lesions in Women at High Risk for Ovarian Cancer: A. Multicenter Study. Cancer Prev. Res. 2018, 11, 697-706. [CrossRef] [PubMed]

50. Werness, B.A.; Parvatiyar, P.; Ramus, S.J.; Whittemore, A.S.; Garlinghouse-Jones, K.; Oakley-Girvan, I.; DiCioccio, R.A.; Wiest, J.; Tsukada, Y.; Ponder, B.A.J.; et al. Ovarian carcinoma in situ with germline BRCA1 mutation and loss of heterozygosity at BRCA1 and TP53. J. Natl. Cancer Inst. 2000, 92, 1088-1091. [CrossRef]

51. Pothuri, B.; Leitao, M.M.; Levine, D.A.; Viale, A.; Olshen, A.B.; Arroyo, O.; Bogomolniy, F.; Olvera, N.; Lin, O.; Soslow, R.A.; et al. Genetic analysis of the early natural history of epithelial ovarian carcinoma. PLoS ONE 2010, 5, e10358. [CrossRef] [PubMed]

52. Soong, T.R.; Howitt, B.E.; Miron, A.; Horowitz, N.S.; Campbell, F.; Feltmate, C.M.; Muto, M.G.; Berkowitz, R.S.; Nucci, M.R.; Xian, W.; et al. Evidence for lineage continuity between early serous proliferations (ESPs) in the Fallopian tube and disseminated high-grade serous carcinomas. J. Pathol. 2018, 246, 344-351. [CrossRef]

53. Banet, N.; Kurman, R.J. Two Types of Ovarian Cortical Inclusion Cysts: Proposed Origin and Possible Role in Ovarian Serous Carcinogenesis. Int. J. Gynecol. Pathol. 2015, 34, 3-8. [CrossRef]

54. Park, K.J.; Patel, P.; Linkov, I.; Jotwani, A.; Kauff, N.; Pike, M.C. Observations on the origin of ovarian cortical inclusion cysts in women undergoing risk-reducing salpingo-oophorectomy. Histopathology 2018, 72, 766-776. [CrossRef]

55. Wang, Y.; Sessine, M.S.; Zhai, Y.; Tipton, C.; McCool, K.; Kuick, R.; Connolly, D.C.; Fearon, E.R.; Cho, K.R. Lineage tracing suggests that ovarian endosalpingiosis does not result from escape of oviductal epithelium. J. Pathol. 2019, 249, 206-214. [CrossRef]

56. Auersperg, N.; Wong, A.S.; Choi, K.C.; Kang, S.K.; Leung, P.C. Ovarian surface epithelium: Biology, endocrinology, and pathology. Endocr. Rev. 2001, 22, 255-288. [CrossRef]

57. Quinn, B.A.; Brake, T.; Hua, X.; Baxter-Jones, K.; Litwin, S.; Ellenson, L.H.; Connolly, D.C. Induction of ovarian leiomyosarcomas in mice by conditional inactivation of Brca1 and p53. PLoS ONE 2009, 4, e8404. [CrossRef]

58. Murakami, R.; Matsumura, N.; Mandai, M.; Yoshihara, K.; Tanabe, H.; Nakai, H.; Yamanoi, K.; Abiko, K.; Yoshioka, Y.; Hamanishi, J.; et al. Establishment of a Novel Histopathological Classification of High-Grade Serous Ovarian Carcinoma Correlated with Prognostically Distinct Gene Expression Subtypes. Am. J. Pathol. 2016, 186, 1103-1113. [CrossRef] [PubMed]

59. Backman, S.; Kollara, A.; Haw, R.; Stein, L.; Brown, T.J. Glucocorticoid-induced reversal of interleukin-1 $\beta$-stimulated inflammatory gene expression in human oviductal cells. PLoS ONE 2014, 9, e97997. [CrossRef] [PubMed]

60. Huang, H.S.; Chu, S.C.; Hsu, C.F.; Chen, P.-C.; Ding, D.-C.; Chang, M.-Y.; Chu, T.-Y. Mutagenic, surviving and tumorigenic effects of follicular fluid in the context of p53 loss: Initiation of fimbria carcinogenesis. Carcinogenesis 2015, 36, 1419-1428. [CrossRef]

61. Lin, S.F.; Gerry, E.; Shih, I.-M. Tubal origin of ovarian cancer-the double-edged sword of haemoglobin. J. Pathol. 2017, 242, 3-6. [CrossRef]

62. Brand, H.; Barnabas, G.D.; Sapoznik, S.; Bahar-Shany, K.; Pozniak, Y.; Yung, Y.; Hourvitz, A.; Geiger, T.; Jacob-Hirsch, J.; Levanon, K. NF- $\mathrm{BB}-\mathrm{miR}-155$ axis activation mediates ovulation-induced oncogenic effects in fallopian tube epithelium. Carcinogenesis 2020, 2, bgaa068.

63. Hsu, C.F.; Huang, H.S.; Chen, P.C.; Ding, D.C.; Chu, T.Y. IGF-axis confers transformation and regeneration of fallopian tube fimbria epithelium upon ovulation. EBioMedicine 2019, 41, 597-609. [CrossRef] [PubMed]

64. Savant, S.S.; Sriramkumar, S.; O'Hagan, H.M. The Role of Inflammation and Inflammatory Mediators in the Development, Progression, Metastasis, and Chemoresistance of Epithelial Ovarian Cancer. Cancers 2018, 10, 251. [CrossRef]

65. Wu, N.Y.; Huang, H.S.; Chao, T.H.; Chou, H.M.; Fang, C.; Qin, C.Z.; Lin, C.Y.; Chu, T.Y.; Zhou, H.H. Progesterone Prevents High-Grade Serous Ovarian Cancer by Inducing Necroptosis of p53-Defective Fallopian Tube Epithelial Cells. Cell Rep. 2017, 18, 2557-2565. [CrossRef]

66. DastranjTabrizi, A.; MostafaGharabaghi, P.; SheikhzadehHesari, F.; Sadeghi, L.; Zamanvandi, S.; Sarbakhsh, P.; Ghojazadeh, M. Impact and mechanistic role of oral contraceptive pills on the number and epithelial type of ovarian cortical inclusion cysts; a clinicopathology and immunohistochemical study. Diagn Pathol. 2016, 11, 30. [CrossRef] [PubMed]

67. Shigeta, S.; Toyoshima, M.; Kitatani, K.; Ishibashi, M.; Usui, T.; Yaegashi, N. Transferrin facilitates the formation of DNA double-strand breaks via transferrin receptor 1: The possible involvement of transferrin in carcinogenesis of high-grade serous ovarian cancer. Oncogene 2016, 35, 3577-3586. [CrossRef]

68. Huang, H.S.; Hsu, C.F.; Chu, S.C.; Chen, P.C.; Ding, D.C.; Chang, M.Y.; Chu, T.Y. Haemoglobin in pelvic fluid rescues Fallopian tube epithelial cells from reactive oxygen species stress and apoptosis. J. Pathol. 2016, 240, 484-494. [CrossRef]

69. Reuter, S.; Gupta, S.C.; Chaturvedi, M.M.; Aggarwal, B.B. Oxidative stress, inflammation, and cancer: How are they linked? Free Radic Biol. Med. 2010, 49, 1603-1616. [CrossRef] 
70. Soria-Valles, C.; López-Soto, A.; Osorio, F.G.; López-Otín, C. Immune and inflammatory responses to DNA damage in cancer and aging. Mech. Ageing Dev. 2017, 165, 10-16. [CrossRef]

71. Zheng, W.; Lu, J.J.; Luom, F.; Zheng, Y.; Feng, Y.-J.; Felix, J.C.; Lauchlan, S.C.; Pike, M.C. Ovarian Epithelial Tumor Growth Promotion by Follicle-Stimulating Hormone and Inhibition of the Effect by Luteinizing Hormone. Gynecol. Oncol. 2000, 76, 80-88. [CrossRef] [PubMed]

72. Huang, Y.; Jin, H.; Liu, Y.; Zhou, J.; Ding, J.; Cheng, K.W.; Yu, Y.; Feng, Y. FSH inhibits ovarian cancer cell apoptosis by up-regulating survivin and down-regulating PDCD6 and DR5. Endocr Relat. Cancer 2010, 18, 13-26. [CrossRef] [PubMed]

73. Xu, J.; Zheng, T.; Hong, W.; Ye, H.; Hu, C.; Zheng, Y. Mechanism for the Decision of Ovarian Surface Epithelial Stem Cells to Undergo Neo-Oogenesis or Ovarian Tumorigenesis. Cell Physiol. Biochem. 2018, 50, 214-232. [CrossRef] [PubMed]

74. Smith, E.R.; Xu, X.X. Ovarian ageing, follicle depletion, and cancer: A hypothesis for the aetiology of epithelial ovarian cancer involving follicle depletion. Lancet Oncol. 2008, 9, 1108-1111. [CrossRef]

75. Lee, A.W.; Tyre, J.P.; Doherty, J.A.; Stram, D.A.; Kupryjanczyk, J.; Dansonka-Mieszkowska, A.; Plisiecka-Halasa, J.; Spiewankiewicz, B.; Myers, E.J.; Australian Cancer Study (Ovarian Cancer); et al. Evaluating the ovarian cancer gonadotropin hypothesis: A candidate gene study. Gynecol. Oncol. 2015, 136, 542-548. [CrossRef] [PubMed]

76. Delaney, J.R.; Patel, C.B.; Bapat, J.; Jones, C.M.; Ramos-Zapatero, M.; Ortell, K.K.; Tanios, R.; Haghighiabyaneh, M.; Axelrod, J.; DeStefano, J.W.; et al. Autophagy gene haploinsufficiency drives chromosome instability, increases migration, and promotes early ovarian tumors. PLoS Genet. 2020, 16, e1008558. [CrossRef]

77. Nesic, K.; Wakefield, M.; Kondrashova, O.; Scott, C.L.; McNeish, I.A. Targeting DNA repair: The genome as a potential biomarker. J. Pathol. 2018, 244, 586-597. [CrossRef]

78. Ahmed, A.A.; Etemadmoghadam, D.; Temple, J.; Lynch, A.G.; Riad, M.; Australian Ovarian Cancer Study Group; Sharma, R.; Stewart, C.; Fereday, S.; Caldas, C.; et al. Driver mutations in TP53 are ubiquitous in high grade serous carcinoma of the ovary. J. Pathol. 2010, 221, 49-56. [CrossRef]

79. Cancer Genome Atlas Research Network. Integrated genomic analyses of ovarian carcinoma. Nature 2011, 474, 609-615. [CrossRef]

80. McGranahan, N.C. Swanton, Clonal heterogeneity and tumor evolution: Past, present, and the future. Cell 2017, 168, 613-628. [CrossRef]

81. Etemadmoghadam, D.; Weir, B.A.; Au-Yeung, G.; Alsop, K.; Mitchell, G.; George, J.; Australian Ovarian Cancer Study Group; Davis, S.; D'Andrea, A.D.; Simpson, A.D.; et al. Synthetic lethality between CCNE1 amplification and loss of BRCA1. Proc. Natl. Acad. Sci. USA 2013, 110, 19489-19494. [CrossRef] [PubMed]

82. Ciriello, G.; Cerami, E.; Sander, C.; Schultz, N. Mutual exclusivity analysis identifies oncogenic network modules. Genome Res. 2012, 22, 398-406. [CrossRef]

83. Delaney, J.R.; Patel, C.B.; Willis, K.M.; Haghighiabyaneh, M.; Axelrod, J.; Tancioni, I.; Lu, D.; Bapat, J.; Young, S.; Cadassou, O.; et al. Haploinsufficiency networks identify targetable patterns of allelic deficiency in low mutation ovarian cancer. Nat. Commun. 2017, 8, 14423. [CrossRef] [PubMed]

84. Bashashati, A.; Ha, G.; Tone, A.; Ding, J.; Prentice, L.M.; Roth, A.; Rosner, J.; Shumansky, K.; Kalloger, S.; Senz, J.; et al. Distinct evolutionary trajectories of primary high-grade serous ovarian cancers revealed through spatial mutational profiling. J. Pathol. 2013, 231, 21-34. [CrossRef]

85. Chien, J.; Sicotte, H.; Fan, J.B.; Humphray, S.; Cunningham, J.M.; Kalli, K.R.; Oberg, A.L.; Hart, S.N.; Li, Y.; Davila, J.I.; et al. TP53 mutations, tetraploidy and homologous recombination repair defects in early stage high-grade serous ovarian cancer. Nucleic Acids Res. 2015, 43, 6945-6958. [CrossRef] [PubMed]

86. Joruiz, S.M.; Bourdon, J.C. p53 Isoforms: Key regulators of the cell fate decision. Cold Spring Harb Perspect Med. 2016,6 , a026039. [CrossRef]

87. Bieging, K.T.; Mello, S.S.; Attardi, L.D. Unravelling mechanisms of p53-mediated tumour suppression. Nat. Rev. Cancer 2014, 14, 359-370. [CrossRef]

88. Macintyre, G.; Goranova, T.E.; De Silva, D.; Ennis, D.; Piskorz, A.M.; Eldridge, M.; Sie, D.; Lewsley, L.A.; Hanif, A.; Wilson, C.; et al. Copy number signatures and mutational processes in ovarian carcinoma. Nat. Genet. 2018, 50, 1262-1270. [CrossRef]

89. Kohler, M.F.; Marks, J.R.; Wiseman, R.W.; Jacobs, I.J.; Davidoff, A.M.; Clarke-Pearson, D.L.; Soper, J.T.; Bast, R.C., Jr.; Berchuck, A. Spectrum of mutation and frequency of allelic deletion of the p53 gene in ovarian cancer. J. Natl. Cancer Inst. 1993, 85, $1513-1519$. [CrossRef]

90. Silwal-Pandit, L.; Langerod, A.; Borresen-Dale, A.-L. TP53 Mutations in Breast and Ovarian Cancer. Cold Spring Harb. Perspect. Med. 2017, 7, a026252.

91. Brachova, P.; Mueting, S.R.; Carlson, M.J.; Goodheart, M.J.; Button, A.M.; Mott, A.L.; Dai, D.; Thiel, K.W.; Devor, E.J.; Leslie, K.K. TP53 oncomorphic mutations predict resistance to platinum and taxane-based standard chemotherapy in patients diagnosed with advanced serous ovarian carcinoma. Int. J. Oncol. 2015, 46, 607-618. [CrossRef]

92. Mandilaras, V.; Garg, S.; Cabanero, M.; Tan, Q.; Pastrello, C.; Burnier, J.; Karakasis, K.; Wang, L.; Dhani, N.C.; Butler, M.O.; et al. TP53 mutations in high grade serous ovarian cancer and impact on clinical outcomes: A comparison of next generation sequencing and bioinformatics analyses. Int. J. Gynecol. Cancer 2019, 29, 346-352. [CrossRef] [PubMed] 
93. Flippova, O.T.; Selenica, P.; Pareja, F.; Vahdatinia, M.; Zhu, Y.; Pei, X.; Riaz, N.; Roche, K.L.; Chi, D.S.; Abu-Rustum, N.R.; et al. Molecular characterization of high-grade serous ovarian cancers occurring in younger and older women. Gynecol. Oncol. 2021. [CrossRef]

94. Kuchenbaecker, K.B.; Hopper, J.L.; Barnes, D.R.; Phillips, K.-A.; Mooij, T.M.; Roos-Blom, M.-J.; Jervis, S.; van Leeuwen, F.E.; Milne, R.L.; Andrieu, N.; et al. Risks of Breast, Ovarian, and Contralateral Breast Cancer for BRCA1 and BRCA2 Mutation Carriers. JAMA 2017, 317, 2402-2416. [CrossRef] [PubMed]

95. Yang, D.; Khan, S.; Sun, Y.; Hess, K.; Shumulevich, I.; Sood, A.K.; Zhang, W. Association of BRCA1 and BRCA2 mutations with survival, chemotherapy sensitivity, and gene mutator phenotype in patients with ovarian cancer. JAMA 2011, 306, 1557-1565. [CrossRef]

96. Schrader, K.A.; Hurlburt, J.; Kalloger, S.E.; Hansford, S.; Young, S.; Huntsman, D.G.; Gilks, B.; McAlpine, J.N. Germline BRCA1 and BRCA2 mutations in ovarian cancer: Utility of a histology-based referral strategy. Obstet Gynecol. 2012, 120, 235-240. [CrossRef]

97. Pathania, S.; Bade, S.; Le Guillou, M.; Burke, K.; Reed, R.; Bowman-Colin, C.; Su, Y.; Ting, D.T.; Polyak, K.; Richardson, A.L.; et al. BRCA1 haploinsufficiency for replication stress suppression in primary cells. Nat. Commun. 2014, 5, 5496. [CrossRef] [PubMed]

98. Konishi, H.; Mohseni, M.; Tamaki, A.; Garay, J.P.; Croessmann, S.; Karnan, S.; Ota, A.; Wong, H.Y.; Konishi, Y.; Karakas, B.; et al. Mutation of a single allele of the cancer susceptibility gene BRCA1 leads to genomic instability in human breast epithelial cells. Proc. Natl. Acad. Sci. USA 2011, 108, 17773-17778. [CrossRef] [PubMed]

99. Maxwell, K.N.; Wubbenhorst, B.; Wenz, B.M.; De Sloover, D.; Pluta, J.; Emery, L.; Barrett, A.; Kraya, A.A.; Anastopoulos, I.N.; $\mathrm{Yu}$, S.; et al. BRCA locus-specific loss of heterozygosity in germline BRCA1 and BRCA2 carriers. Nat. Commun. 2017, 8, 319. [CrossRef]

100. Perets, R.; Wyant, G.A.; Muto, K.W.; Bijron, J.G.; Poole, B.B.; Chin, K.T.; Chen, J.Y.H.; Ohman, A.W.; Stepule, C.D.; Kwak, S.; et al. Transformation of the fallopian tube secretory epithelium leads to high-grade serous ovarian cancer in Brca; Tp53; Pten models. Cancer Cell 2013, 24, 751-765. [CrossRef]

101. Austria, T.; Marion, C.; Yu, V.; Widschwendter, M.; Hinton, D.R.; Dubeau, L. Mechanism of cytokinesis failure in ovarian cystadenomas with defective BRCA1 and P53 pathways. Int. J. Cancer 2018, 143, 2932-2942. [CrossRef]

102. Roy, R.; Chun, J.; Powell, S.N. BRCA1 and BRCA2: Different roles in a common pathway of genome protection. Nat. Rev. Cancer 2012, 12, 68-78. [CrossRef]

103. Hyman, D.M.; Zhou, Q.; Iasonos, A.; Grisham, R.N.; Arnold, A.G.; Phillips, M.F.; Bhatia, J.; Levine, D.A.; Aghajanian, C.; Offit, K.; et al. Improved survival for BRCA2-associated serous ovarian cancer compared with both BRCA-negative and BRCA1-associated serous ovarian cancer. Cancer 2012, 118, 3703-3709. [CrossRef] [PubMed]

104. Konstantinopoulos, P.A.; Ceccaldi, R.; Shapiro, G.I.; D'Andrea, A.D. Homologous recombination deficiency: Exploiting the fundamental vulnerability of ovarian cancer. Cancer Discov. 2015, 5, 1137-1154. [CrossRef] [PubMed]

105. Riaz, N.; Blecua, P.; Lim, R.S.; Shen, R.; Higginson, D.S.; Weinhold, N.; Norton, L.; Weigelt, B.; Powell, S.N.; Reis-Filho, J.S.; et al. Pan-cancer analysis of bi-allelic alterations in homologous recombination DNA repair genes. Nat. Commun. 2017, 8, 857. [CrossRef]

106. Kuhn, E.; Wang, T.-L.; Doberstein, K.; Bahadirli-Talbott, A.; Ayhan, A.; Sehdev, A.S.; Drapkin, R.; Kurman, R.J.; Shih, I.-M. CCNE1 amplification and centrosome number abnormality in serous tubal intraepithelial carcinoma: Further evidence supporting its role as a precursor of ovarian high-grade serous carcinoma. Mod. Pathol. 2016, 29, 1254-1261. [CrossRef] [PubMed]

107. Hwang, H.C.; Clurman, B.E. Cyclin E in normal and neoplastic cell cycles. Oncogene 2005, 24, 2776-2786. [CrossRef]

108. Chan, A.M.; Enwere, E.; McIntyre, J.B.; Wilson, H.; Nwaroh, C.; Wiebe, N.; Ou, Y.; Liu, S.; Wiedemeyer, K.; Rambau, P.F.; et al. Combined CCNE1 high-level amplification and overexpression is associated with unfavourable outcome in tubo-ovarian high grade serous carcinoma. J. Pathol. Clin. Res. 2020, 6, 252-262. [CrossRef]

109. Singh, S.S.; Vats, S.; Chia, A.Y.; Tan, T.Z.; Deng, S.; Ong, M.S.; Arfuso, F.; Yap, C.T.; Goh, B.C.; Sethi, G.; et al. Dual role of autophagy in hallmarks of cancer. Oncogene 2018, 37, 1142-1158. [CrossRef]

110. Ferraresi, A.; Girone, C.; Esposito, A.; Vidoni, C.; Vallino, L.; Secomandi, E.; Dhanasekaran, D.N.; Isidoro, C. How Autophagy Shapes the Tumor Microenvironment in Ovarian Cancer. Front. Oncol. 2020, 10, 599915. [CrossRef]

111. Ngabire, D.; Kim, G.D. Autophagy and Inflammatory Response in the Tumor Microenvironment. Int. J. Mol. Sci. 2017, 18, 2016. [CrossRef] [PubMed]

112. Folkerts, H.; Hilgendorf, S.; Vellenga, E.; Bremer, E.; Wiersma, V.R. The multifaceted role of autophagy in cancer and the microenvironment. Med. Res. Rev. 2019, 39, 517-560. [CrossRef]

113. Chui, M.H.; Wang, Y.; Wu, R.-C.; Seidman, J.; Kurman, R.J.; Wan, T.-L.; Shih, I.-M. Loss of ALDH1A1 expression is an early event in the pathogenesis of ovarian high-grade serous carcinoma. Mod. Pathol. 2015, 28, 437-445. [CrossRef] [PubMed]

114. Wen, Y.; Hou, Y.; Huang, Z.; Cai, J.; Wang, Z. SOX2 is required to maintain cancer stem cells in ovarian cancer. Cancer Sci. 2017, 108, 719. [CrossRef] [PubMed]

115. Hellner, K.; Miranda, F.; Fotso, D.C.; Herrero-Gonzalez, S.; Hayden, D.M.; Tearle, R.; Artibani, M.; KaramiNejadRanjbar, M.; Williams, R.; Gaitskell, K.; et al. Premalignant SOX2 overexpression in the fallopian tubes of ovarian cancer patients: Discovery and validation studies. EBioMedicine 2016, 10, 137-149. [CrossRef] 
116. Boyd, C.; McCluggage, W.G. Low-Grade Ovarian Serous Neoplasms (Low-Grade Serous Carcinoma and Serous Borderline Tumor) Associated With High-Grade Serous Carcinoma or Undifferentiated Carcinoma: Report of a Series of Cases of an Unusual Phenomenon. Am. J. Surg. Pathol. 2012, 36, 368-375. [CrossRef]

117. Emmanuel, C.; Chiew, Y.E.; George, J.; Etemadmoghadam, D.; Anglesio, M.S.; Sharma, R.; Russell, P.; Kennedy, C.; Fereday, S.; Hung, J.; et al. Genomic classification of serous ovarian cancer with adjacent borderline differentiates RAS pathway and TP53-mutant tumors and identifies NRAS as an oncogenic driver. Clin. Cancer Res. 2014, 20, 6618-6630. [CrossRef]

118. Vang, R.; Levine, D.A.; Soslow, R.A.; Zaloudek, C.; Shih, I.e.M.; Kurman, R.J. Molecular alterations of TP53 are a defining feature of ovarian high-grade serous carcinoma: A Rereview of cases lacking TP53 mutations in the cancer genome atlas ovarian study. Int. J. Gynecol. Pathol. 2016, 35, 48-55. [CrossRef] [PubMed]

119. Kotsopoulos, J.; Lubinski, J.; Gronwald, J.; Cybulski, C.; Demsky, R.; Neuhausen, S.L.; Kim-Sing, C.; Tung, N.; Friedman, S.; Senter, L.; et al. Factors influencing ovulation and the risk of ovarian cancer in BRCA1 and BRCA2 mutation carriers. Int. J. Cancer 2015, 137, 1136-1146. [CrossRef]

120. Trabert, B.; Ness, R.B.; Lo-Ciganic, W.H.; Murphy, M.A.; Goode, E.L.; Poole, E.M.; Brinton, L.A.; Webb, P.M.; Nagle, C.M.; Jordan, S.J.; et al. Aspirin, nonaspirin nonsteroidal antiinflammatory drug, and acetaminophen use and risk of invasive epithelial ovarian cancer: A pooled analysis in the Ovarian Cancer Association Consortium. J. Natl. Cancer Inst. 2014, 106, djt431. [CrossRef]

121. Labidi-Galy, S.I.; Papp, E.; Hallberg, D.; Niknafs, N.; Adleff, V.; Noe, M.; Bhattachaya, R.; Novak, M.; Jones, S.; Phallen, J.; et al. High grade serous ovarian carcinomas originate in the fallopian tube. Nat. Commun. 2017, 8, 1093. [CrossRef]

122. Wu, R.C.; Wang, P.; Lin, S.F.; Zhang, M.; Song, Q.; Chu, T.; Wang, B.G.; Kurman, R.J.; Vang, R.; Kinzler, K.; et al. Genomic landscape and evolutionary trajectories of ovarian cancer precursor lesions. J. Pathol. 2019, 248, 41-50. [CrossRef]

123. Gerstung, M.; Jolly, C.; Leshchiner, I.; Dentro, S.C.; Gonzalez, S.; Rosebrock, D.; Mitchell, T.J.; Rubanova, Y.; Anur, P.; Yu, K.; et al. The evolutionary history of 2,658 cancers. Nature 2020, 578, 122-128. [CrossRef] [PubMed]

124. Otsuka, I.; Kameda, S.; Hoshi, K. Early detection of ovarian and fallopian tube cancer by examination of cytological samples from the endometrial cavity. Br. J. Cancer 2013, 109, 603-609. [CrossRef] [PubMed]

125. Van Nagell, J.R., Jr.; Burgess, B.T.; Miller, R.W.; Baldwin, L.; DeSimone, C.P.; Ueland, E.R.; Huang, B.; Chen, Q.; Kryscio, R.J.; Pavlik, E.J. Survival of Women With Type I and II Epithelial Ovarian Cancer Detected by Ultrasound Screening. Obstet Gynecol. 2018, 132, 1091-1100. [CrossRef]

126. Ledermann, J.A.; Drew, Y.; Kristeleit, R.S. Homologous recombination deficiency and ovarian cancer. Eur. J. Cancer 2016, 60, 49-58. [CrossRef]

127. Jonsson, P.; Bandlamudi, C.; Cheng, M.L.; Srinivasan, P.; Chavan, S.S.; Friedman, N.D.; Rosen, E.Y.; Richards, A.L.; Bouvier, N.; Selcuklu, S.D.; et al. Tumour lineage shapes BRCA-mediated phenotypes. Nature 2019, 571, 576-579. [CrossRef]

128. Etemadmoghadam, D.; de Fazio, A.; Beroukhim, R.; Mermel, C.; George, J.; Getz, G.; Tothill, R.; Okamoto, A.; Raeder, M.B.; AOCS Study Group; et al. Integrated genome-wide DNA copy number and expression analysis identifies distinct mechanisms of primary chemoresistance in ovarian carcinomas. Clin. Cancer Res. 2009, 15, 1417-1427. [CrossRef]

129. Patch, A.M.; Christie, E.L.; Etemadmoghadam, D.; Garsed, D.W.; George, J.; Fereday, S.; Nones, K.; Cowin, P.; Alsop, K.; Bailey, P.J.; et al. Whole-genome characterization of chemoresistant ovarian cancer. Nature 2015, 521, 489-494. [CrossRef] [PubMed]

130. Strickland, K.C.; Howitt, B.E.; Shukla, S.A.; Rodig, S.; Ritterhouse, L.L.; Liu, J.F.; Garber, J.E.; Chowdhury, D.; Wu, C.J.; D’Andrea, A.D.; et al. Association and prognostic significance of BRCA1/2-mutation status with neoantigen load, number of tumorinfiltrating lymphocytes and expression of PD-1/PD-L1 in high grade serous ovarian cancer. Oncotarget 2016, 7, 13587-13598. [CrossRef] [PubMed]

131. Wieser, V.; Gaugg, I.; Fleischer, M.; Shivalingaiah, G.; Wenzel, S.; Sprung, S.; Lax, S.F.; Zeimet, A.G.; Fiegl, H.; Marth, C. BRCA1/2 and TP53 mutation status associates with PD-1 and PD-L1 expression in ovarian cancer. Oncotarget 2018, 9, 17501-17511. [CrossRef] [PubMed]

132. Lee, S.; Zhao, L.; Rojas, C.; Baterman, N.W.; Yao, H.; Lara, O.D.; Celestino, J.; Morgan, M.B.; Nguyen, T.V.; Conrads, K.A.; et al. Molecular Analysis of Clinically Defined Subsets of High-Grade Serous Ovarian Cancer. Cell Rep. 2020, 31, 107502. [CrossRef] [PubMed]

133. Mittempergher, L. Genomic Characterization of High-Grade Serous Ovarian Cancer: Dissecting Its Molecular Heterogeneity as a Road Towards Effective Therapeutic Strategies. Curr. Oncol. Rep. 2016, 18, 44. [CrossRef]

134. Schwarz, R.F.; Ng, C.K.; Cooke, S.L.; Newman, S.; Temple, J.; Piskorz, A.M.; Gale, D.; Sayal, K.; Murtaza, M.; Baldwin, P.J.; et al. Spatial and temporal heterogeneity in high-grade serous ovarian cancer: A phylogenetic analysis. PLoS Med. 2015, 12, e1001789. [CrossRef]

135. Castellarin, M.; Milne, K.; Zeng, T.; Tse, K.; Mayo, M.; Zhao, Y.; Webb, J.R.; Watson, P.H.; Nelson, B.H.; Holt, R.A.; et al. Clonal evolution of high-grade serous ovarian carcinoma from primary to recurrent disease. J. Pathol. 2013, 229, 515-524. [CrossRef]

136. McGranahan, N.; Swanton, C. Biological and Therapeutic Impact of Intratumor Heterogeneity in Cancer Evolution. Cancer Cell 2015, 27, 15-26. [CrossRef]

137. Roberts, C.M.; Cardenas, C.; Tedja, R. The Role of Intra-Tumoral Heterogeneity and Its Clinical Relevance in Epithelial Ovarian Cancer Recurrence and Metastasis. Cancers 2019, 11, 1083. [CrossRef] [PubMed]

138. Kotsopoulos, J.B.; Rosen, I.; Fan, J.; Moody, J.R. McLaughlin, H.R.; Risch, H.; May, T.; Sun, P.; Narod, S.A. Ten-year survival after epithelial ovarian cancer is not associated with BRCA mutation status. Gynecol. Oncol. 2016, 140, 42-47. [CrossRef] [PubMed] 